Nigerian Journal of Physiological Sciences 23 (1-2): 23-26 CPhysiological Society of Nigeria, 2008

Available online/abstracted at http://www.bioline.org.br/np; www.ajol.info/journals.nips; www.cas.org

\title{
ANTIULCER AND GASTRIC ANTISECRETORY EFFECTS OF LANDOLPHIA OWARIENSIS EXTRACTS IN RATS
}

\author{
SAMUEL. B. OLALEYE, VICTOR B. OWOYELE ${ }^{1}$ and A. O. ODUKANMI
}

\author{
Gastrointestinal Research Unit, Department of Physiology, College of Medicine, University of Ibadan, Ibadan, Nigeria \\ ${ }^{I}$ Department of Physiology, College of Health Sciences, University of Ilorin. Ilorin, Nigeria \\ E-mail: olaleye_ui@hotmail.com, sb.olaleye@mail.ui.edu.ng
}

\begin{abstract}
Summary: Water, Methanol and Chloroform Extracts of Landolphia owarensis were investigated for their effects on gastric acid secretion and ulceration in male albino rats. Two models of gastric lesion induced in experimental Wistar rats- HC1/ethanol- induced gastric lesions and Pylorus ligation-induced gastric lesions - were employed. In both models, the antiulcer activity of LA was compared with that of cimetidine (100 $\mathrm{mg} \mathrm{kg} \mathrm{p.o.).} \mathrm{In} \mathrm{the} \mathrm{HCl} / \mathrm{Ethanol} \mathrm{model,}$ ulcer index and mucus production was determined. In pylorus ligated rat, ulcer index, mucus production, total volume of gastric juice and gastric acidity level were measured. Pre-treatment of animals with the aqueous extracts $(100 \mathrm{mg} / \mathrm{kg}$ and $200 \mathrm{mg} / \mathrm{kg}$ ) orally once daily for two weeks significantly reduced formation of ulcers induced by $\mathrm{HCl} / \mathrm{ethanol}$ mixture, the percentage inhibition being $43.8 \%$ and $55.27 \%$ respectively. The Chloroform extract afforded the least protection with $23.07 \%$ and $14.77 \%$ inhibition. This was also accompanied by significant increases in gastric mucus production. In pylorus ligated rats, total volume of gastric juice and gastric acidity was significantly decreased as compared to control group, to levels comparable to that produced by cimetidine. The results indicate that the leaf extracts of LO contains antiulcer principles.
\end{abstract}

Keywords: Landolphia owariensis, antiulcer, gastric secretion, rat

\section{Introduction}

Peptic ulcer is a common disease throughout the world and in the past one or two decades there has been a phenomenal increase in the contribution to knowledge on the treatment of the disease (Odaibo, 1988). The protective effects of some medicinal plant species have been investigated for anti-ulcer properties. Such plants include Egletes viscosa (Rao et al, 1997), Garcinia kola seeds (Ibironke et al, 1997), Picronrhiza kurroa (Anaden et al, 1999).

Landophia owariensis P. beauv. (family Apocynaceae) commonly called vine rubber and known locally by various names in Nigeria- Nwalikali or Mba (Ibo); Panukuro or Ibo akitipa (Yoruba) and Ciwo or Kuranga (Hausa) - is widely used locally for the treatment of many ailments. The decoction of leaves is used as a purgative and to cure malaria. In the southwestern Nigeria, the leaf decoction is employed in the treatment of stomach pain and ulcer. The root is soaked in local gin for about a week and the extract given two full wine glass a day to cure gonorrhea (Gill, 1992). Lewis and Lewis (1977) also reported the use of stem bark as vermifuge. The latex is drunk or used in french Equatorial Africa as an enema for intestinal worms and in parts of Ivory Coast the latex forms an ingredient arrow poison (Irvine 1961). It is used to make native bear and beverage in senegal and upper Nile land respectively (Dalziel, 1937).

Very few reports are available in literature to establish the anecdotal uses of this plant. Ebi and Ofoefule (1997) have validated the folkloric use of Landolphia Owariensis as an antimicrobial agent while the anti-inflammatory and analgesic properties have been reported (Owoyele et al, 2001). In this study the effect of various extracts of the leaves of Landolphia owariensis on experimental ulceration was investigated.

\section{Materials and Methods \\ Plant Material:}

L. Owariensis leaves was collected from their natural habitat at Gambari forest reserve, Oyo State Nigeria and authenticated by a Taxonomist of the forestry research institute of Nigeria (FRIN) Ibadan. Identification of the plant took place at FRIN by the same Taxonomist. A voucher specimen (FHI 105678) has been deposited in the Herbarium of the same institution.

\section{Extract Preparation:}

Air dried and powdered leaves of L. Owariensis were extracted successfully with water, Methanol and Chloroform at $80^{\circ} \mathrm{C}, 40^{\circ} \mathrm{C}$ and room temperature respectively. The dried extract was stored at $40^{\circ} \mathrm{C}$ until they were ready for use. The extract yields of the plant were $1.2 \mathrm{~g}, 3.0 \mathrm{~g}$ and $2.0 \mathrm{~g}$ from $20.0 \mathrm{~g}, 30.0 \mathrm{~g}$ and $20.0 \mathrm{~g}$ of powdered leaves in $150 \mathrm{ml}$ water, $300 \mathrm{~m} 1$ methanol and $250 \mathrm{ml}$ of chloroform respectively. The aqueous extract (AELO) was dissolved in $0.9 \%$ saline while the methanol extract (MELO) and chloroform extract (CELO) were each dissolved in $2.5 \%$ Tween 80 and subsequently in normal saline.

\section{Animals}

Adult male albino rats weighing between 120$150 \mathrm{~g}$ obtained from the animal house of the College of Medicine, University of Ibadan, Nigeria were used. 
They were housed in cages at room temperature with free access to rat cubes (Ladokun Feeds Nig- Limited, Ibadan, Nigeria).

\section{Pepsin binding activity:}

The method described by Rifat-uz-Zaman et al (2002) was essentially followed. Briefly, 500mg powdered AELO, MELO and CELO were added to $2 \mathrm{~mL}$ of pepsin solution $\left(2 \mathrm{mg} / \mathrm{mL}^{-1}\right)$ each in the separate test tubes. $4 \mathrm{mls}$ of $0.2 \mathrm{~N} \mathrm{HC} 1$ buffered with 1 $\mathrm{mL}$ of $0.2 \mathrm{~N}$ sodium citrate solution was then added. Thereafter, one milliter of bovine semm albumin $(5 \mathrm{mg}$ $\mathrm{mL}^{-1}$ ) was added to treat the excess pepsin except control test tubes, pre-incubation at $37^{\circ} \mathrm{C}$ for $30 \mathrm{~min}$. The contents were further incubated at $37^{\circ} \mathrm{C}$ for $30 \mathrm{~min}$ following shaking. Remaining protein in each tube was treated with $1.0 \mathrm{~mL}$ of Biuret reagent and alkalized by adding $5 \mathrm{~mL} 0.2 \mathrm{~N} \mathrm{NaOH}$ solution. Their absorbances were read at $546 \mathrm{~nm}$. The values obtained were expressed as percentage binding of pepsin.

\section{HCl/Ethanol-Induced Ulcers}

After a 2-week administration of $100 \mathrm{mg} / \mathrm{kg}$ and $200 \mathrm{mg} / \mathrm{kg}$ of the extracts of Landolphia owariensis (AELO, MELO and CELO) and vehicle (0.1ml, 25\% Tween 80), all the groups had their food withdrawn 24hours but allowed free access to water. Afterwards, $1 \mathrm{ml}$ of $\mathrm{HCl} /$ ethanol mixture containing $0.15 \mathrm{~N} \mathrm{HC} 1$ in $70 \% \mathrm{v} / \mathrm{v}$ ethanol was administered orally. The rats were sacrificed $1 \mathrm{hr}$ later by ether overdose and the stomachs removed and observed for lesions in the glandular portion. Ulcers were independently assessed and scored by two observers using the method of Rao et al. (1997) as follows: $0=$ no ulcers (normal stomach) ; $1=$ up to 5 petechial hemorrhages, $2=$ up to 5 petechial hemorrhages with erosions of depth $1 \mathrm{~mm}$, $3=$ up to 10 petechial haemorrhages with erosions of depth $1 \mathrm{~mm} ; 4$ = up to 10 petechial hemorrhages with erosion of depth above $1 \mathrm{~mm}$.

\section{Pylorus-ligated gastric secretion and ulceration \\ Oral administration of $100 \mathrm{mg} / \mathrm{kg}$ and $200 \mathrm{mg} / \mathrm{kg}$ of the extract of Landolphia owariensis (AELO, MELO and CELO) and vehicle (0.1ml, 25\% Tween 80) was done for two weeks. After treatments, all the animals were subjected to surgery under light ether anaesthesia according to Brodie (1966) The 4h gastric juice collection was drained into a graduated test tube and centrifuged at 2000rpm for 10min. The supernatant volume and $\mathrm{pH}$ were recorded. The total acid content of the gastric juice was also determined by titration to $\mathrm{pH} 7.0$ with $0.05 \mathrm{~N} \mathrm{NaOH}$, using phenolphthalein as indicator. Ulcers formed in the glandular portion of the stomachs were scored as previously described.}

\section{Measurement of mucus production}

Gastric mucus production was measured in the rats that were subjected to $\mathrm{HCl} /$ ethanol induced lesions. After estimating the degree of lesion formation, the gastric mucosa of each rat was gently scraped using a glass slide. The gastric barrier mucous was estimated by the method of Corne et al (1974). Briefly, the excised stomachs from the rats were soaked for 2 hours in $0.1 \%$ Alcian blue dissolved in buffer solution containing $0.1 \mathrm{M}$ sucrose and $0.05 \mathrm{M}$ Sodium acetate ( $\mathrm{pH}$ adjusted to 5.8 with hydrochloric acid). After washing the stomach twice in $0.25 \mathrm{M}$ sucrose (15 and $45 \mathrm{~min}$ ), the dye complexed with mucous was eluted by immersion in $10 \mathrm{ml}$ aliquots of $0.5 \mathrm{M} \mathrm{MgCl}_{2}$ for 2 hours. The resulting blue solution was shaken with equal volumes of diethyl ether and the optical density of the aqueous phase measured at $605 \mathrm{nM}$ using a spectrophotometer.

\section{Statistical Analysis}

All values presented in tables are expressed as means \pm Standard error of Means (SEM). Comparisons between groups were made using student's t- test. The difference between the groups is taken to be significant at $\mathrm{P}<0.05$.

\section{Results}

Effect of Extracts of Landolphia owarensis on protein binding

The in-vitro binding activities of the extracts are shown in Fig. 1. The Aqueous, methanol and chloroform extracts of Landolphia owarensis afforded $24.22 \%, 30.53 \%$ and $36.42 \%$ pepsin binding capacities respectively. No noticeable binding was observed in the standard tube.

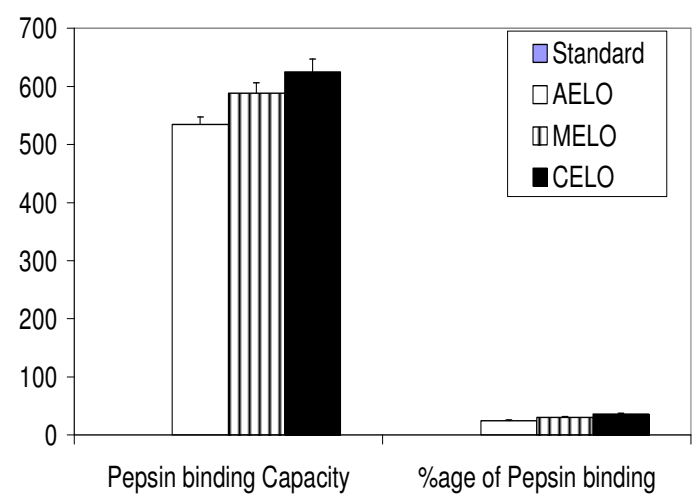

Fig. 1.

Pepsin binding activities of $200 \mathrm{mmg} / \mathrm{kg}$ of aqueuos (AELO), Methanol (MELO) and Chloroform (CELO) extracts of Landolphia owarensis

\section{HCl/Ethanol induced lesion}

Treatment of animals with the $\mathrm{HCl} /$ ethanol mixture $(0.15 \mathrm{~N} \mathrm{HCl}$ in $70 \% \mathrm{~V} / \mathrm{V}$ ethanol) induced visible gastric ulceration characterized by elongated bands parallel to the greater axis of the stomach. As shown in Table 1, animals (pre-treated with normal saline) given $\mathrm{HCl} /$ Ethanol mixture had mean ulcer score of $23.70 \pm 3.15$ and an ulcer index of the same value. Pre-treatment of animals with the aqueous extracts $(100 \mathrm{mg} / \mathrm{kg}$ and $200 \mathrm{mg} / \mathrm{kg})$ significantly reduced formation of ulcers induced by $\mathrm{HCl} / \mathrm{ethanol}$ mixture, the percentage inhibition being $43.8 \%$ and 
$55.27 \%$ respectively. The Chloroform extract afforded the least protection with $23.07 \%$ and $14.77 \%$ inhibition. In this model of ulcer, the standard drug, Cimetidine $(100 \mathrm{mg} / \mathrm{kg})$ afforded a $54.5 \%$ protection on ulcer. There was also a dose dependent increase in mucus secretion in the extract treated animals.

Pylorus-ligated gastric secretion and ulceration

Pylorus ligation for $4 \mathrm{~h}$ resulted in the accumulation of gastric secretion and increase in the titratable acidity. Extracts produced dose-dependent significant decrease in the volume of gastric juice, titratable acidity and ulcer index as compared to control (Table 2). However, mucous production was significantly increased in the extract treated animals.

\section{Discussion}

Peptic ulcer is the most common chronic illness of the digestive system which causes symptoms of upper abdominal pain, fullness, gas and bloating. In some patients, it may also give rise to serious complications such as bleeding, bowel perforation, and obstruction. Ulcer bleeding, a common reason for emergency hospital admission, is the basis for most laboratory evaluation of antiulcer activity of local plants. Many plants are known to have a long history of use for soothing inflamed and injured mucous membranes in the digestive tract. For example, Licorice may protect the stomach and duodenum by increasing production of mucin, (Goso et al, 1996). Moreover, some active components of plants have been shown to confer antiulcer properties on certain plants. Consequently, reports of laboratory research have shown that compounds like flavonoids may inhibit growth of $H$. pylori, in addition to their direct cytoprotective effects (Beil et al, 1995).
The results of the present study have shown that the extracts of the investigated plant exhibit potent and dose related anti-ulcerogenic activities. Moreover, the aqueous extract produced a more effective cytoprotection to the mucosa. These activities may be linked to the reported presence of flavonoidal compounds (Owoyele et al, 2001) in L. Owariensis. Many plants with flavonoidal activities have been shown to be promising in the development of potent antiulcer drugs (Olaleye and Farombi, 2006).

The high in-vitro pepsin binding activities of the extracts may suggest a possible and considerable invivo binding to substrate proteins by a non-specific hydrophobic interaction to form complexes which are less vulnerable to peptic hydrolysis. However, this is just an hypothesis to which further studies may throw more light on. There was a strong correlation between the protection afforded against experimental ulcers by the extracts and the mucous secretion. It is known that the layer of mucus which lines the gastrointestinal tract serves not only as a lubricant but equally more important, as a protective barrier between the mucosal surface and the luminal contents. In conditions where the integrity of the wall of the gastrointestinal tract is threatened, gastric mucous production may be increased. In addition, the biochemical characteristics of the component mucin molecules may change (Jass and Walsh, 2001). The extracts of L.O. may therefore be affording their gastroprotective effects via an increase in the defensive mechanisms of the stomach. Further studies are however needed to elucidate the unknown facts about the gastroprotectiive effects this plant. In conclusion, the overall finding of this study is that L. owariensis posses antiulcer properties and may be a promising material for treatment of ulcerogenesis and gastric mucosal injury.

Table 1: Effect of Extracts of Landolphia owarensis on gastric lesions induced by HCl/Ethanol in rats

\begin{tabular}{|c|c|c|c|c|}
\hline $\begin{array}{l}\text { Treatment and dose }(\mathrm{mg} \mathrm{kg} \\
\text { body weight, orally) } \\
\text { Control }(1 \mathrm{ml})\end{array}$ & $\begin{array}{l}\text { Mucus production } \\
(\mathrm{mg}) \\
20.50 \pm 1.55\end{array}$ & $\begin{array}{l}\text { Ulcer score } \\
\text { Mean } \pm \mathrm{SE} \\
23.7 \pm 4.91\end{array}$ & $\begin{array}{l}\text { Ulcer index } \\
\text { Mean } \\
23.70\end{array}$ & $\begin{array}{l}\% \text { inhibition } \\
-\end{array}$ \\
\hline Vehicle (Tween 80) & $20.8 \pm 1.24^{\mathrm{NS}}$ & $22.20 \pm 1.69$ & 22.20 & 6.33 \\
\hline AELO (100mg/kg) & $27.1 \pm 1.35^{* *}$ & $13.30 \pm 2.58 * *$ & 13.30 & 43.80 \\
\hline AELO (200mg/kg) & $30.6 \pm 1.14 * * *$ & $10.60 \pm 1.02 * *$ & 10.60 & 55.27 \\
\hline MELO (100mg/kg) & $25.3 \pm 1.79 *$ & $13.60 \pm 2.56^{* *}$ & 13.60 & 42.62 \\
\hline MELO (200mg/kg) & $27.1 \pm 2.02 * *$ & $11.60 \pm 2.25^{* *}$ & 11.60 & 50.89 \\
\hline CELO (100mg/kg) & $25.2 \pm 2.00 *$ & $18.10 \pm 3.23^{\mathrm{NS}}$ & 18.10 & 23.63 \\
\hline CELO (200mg/kg) & $25.9 \pm 1.77 *$ & $16.00 \pm 1.90^{*}$ & 16.10 & 32.49 \\
\hline Cimetidine $(100 \mathrm{mg} / \mathrm{kg})$ & $33.2 \pm 1.20 * * *$ & $7.63 \pm 0.98 * *$ & 7.63 & 67.81 \\
\hline
\end{tabular}

$*<005 p<0.01$ and $* * *<0001$ Student's t-test, All treated groups were statistically compared to control group,

Six rats were used in each group 
Olaleye S. B. et al

Table 2: Ulcer index and Gastric juice parameters in rats with pylorus ligated stomach

\begin{tabular}{|c|c|c|c|c|}
\hline $\begin{array}{l}\text { Treatment and dose } \\
\text { (mg kg body weight, } \\
\text { orally) }\end{array}$ & $\begin{array}{l}\text { Ulcer index } \\
\text { Mean } \pm \text { SE }\end{array}$ & $\begin{array}{l}\text { Gastric juice } \\
\text { Vol (ml/4hr) }\end{array}$ & $\mathrm{pH}$ & $\begin{array}{l}\text { Acid output } \\
\left(\mathrm{x} 10^{4}\right. \\
\mathrm{mmol} / 4 \mathrm{hr})\end{array}$ \\
\hline Control & $10.30 \pm 2.91$ & $4.6 \pm 0.1$ & $2.30 \pm 0.22$ & $7.33 \pm 0.42$ \\
\hline Vehicle (Tween 80) & $10.60 \pm 1.69$ & $4.3 \pm 0.1$ & $2.55 \pm 0.13$ & $7.55 \pm 1.12$ \\
\hline AELO (100mg/kg) & $7.30 \pm 2.58 * *$ & $2.8 \pm 0.2^{* *}$ & $3.45 \pm 0.32$ & $5.17 \pm 1.98$ \\
\hline AELO (200mg/kg) & $5.60 \pm 1.02 * *$ & $2.2 \pm 0.2 * * *$ & $3.80 \pm 0.12$ & $4.34 \pm 2.02$ \\
\hline MELO (100mg/kg) & $7.60 \pm 2.56^{* *}$ & $3.3 \pm 0.2 *$ & $3.20 \pm 0.11$ & $5.53 \pm 1.74$ \\
\hline MELO (200mg/kg) & $6.20 \pm 2.25 * *$ & $3.1 \pm 0.1 *$ & $3.00 \pm 0.15$ & $5.09 \pm 2.11$ \\
\hline CELO (100mg/kg) & $9.40 \pm 3.23^{\mathrm{NS}}$ & $3.5 \pm 0.3^{\mathrm{NS}}$ & $2.85 \pm 0.28$ & $6.67 \pm 2.87$ \\
\hline CELO (200mg/kg) & $7.60 \pm 1.90^{*}$ & $3.2 \pm 0.3^{*}$ & $2.75 \pm 0.37$ & $6.07 \pm 1.55$ \\
\hline Cimetidine $(100 \mathrm{mg} / \mathrm{kg})$ & $4.50 \pm 0.98 * *$ & $2.1 \pm 0.2 * * *$ & $3.85 \pm 0.22$ & $3.42 \pm 1.54$ \\
\hline
\end{tabular}

\section{References}

Beil, W., Birkholz W., Sewing, K.. F. (1995). Effects of flavonoids on parietal cell acid secretion, gastric mucosal prostaglandin production and Helicobacter pylori growth. Arzneimittelforschung;45:697-700.

Black,, J. W., Duncan, W. .A. and Durant, C. .J. (1972). Definition and antagonism of histamine H2-receptor. Nature 236, - 385.

Corne, S. J., Morrissey, S. M. and Woods, R. J. (1974). A method for the quantitative estimation of gastric barrier mucous. J. Physiol. 242: 116P - 117P.

Ebi, C. C. and Ofoefule, S. I. (1997). Investigation into the folkloric anti-microbial activities of Landolphia Owarensis. Phytother. Res. 11(2): 149-151.

Elegbe, R. A. (1978). Comparative studies on starvation and indomethacin induced ulceration in rats. Biochem. Exp. Biol. 16: 159 - 166.

Gill, L. S. (1992). Ethnomedical uses of plants in Nigeria. P. 145 Benin, University of Benin press.

Goso, Y., Ogata, Y., Ishihara, K. and Hotta, K. (1996). Effects of traditional herbal medicine on gastric mucin against ethanol-induced gastric injury in rats. Comp. Biochem. Physiol. 113: C17-21.

Ibironke, G. F., Olaleye, S. B., Balogun, O. and Aremu, D. A. (1997). Antiulcerogenic effect of diet containing seeds of Garcinia kola (Heckel). Phytother. Res. 11: 312 - 313.

Jass, J. R. and Walsh, M. D. (2001). Altered mucin expression in the gastrointestinal tract: a review. $J$. Cell.Mol..Med. 5 (3): 327 - 351.

Martin-Aragon, S., Benedi, J. and Villar, A .(1994). Studies on the anti-inflammatory and ulcerogenic activities of Tubera lignosa extract in experimental animal. Int. J. Pharmacog. 32(1): 33-36.

Merguy, R. and Desbailets, L. (1967). Role of inhibition of gastric mucus secretion in the phenomenon of gastric mucosal damage by indomethacin. Am J. Dig. Dis 12: 862.

Odaibo, S. K. (1988). Current concept in the management of peptic ulcer disease: Nigerian Med. Practitioner 15(3): 37-41.

Olaleye, S. B. and Farombi, E. O. (2006). Attenuation of Indomethacin- and $\mathrm{HCl} /$ Ethanol-induced oxidative gastric mucosa damage in rats by kolaviron (Garcinia biflavanones). Phytother. Res. 20: $14-20$

Owoyele, B.V, Olaleye S.B, Oke, J.M. and Elegbe, R.A. (2001). Anti inflammatory and analgesic activities of leaf extract of Landolphia owariensis. Afr. J. Biomed. Res. (4): 131-133.

Rao, V. N. S., Santos, F. A., Sobreira, T. T., Souza, M. F., Melo, C. L. and Silveira, E. R. (1996). Investigation on the gastroprotective and antidiarhoeal properties of tematin, a tetramethoxyflavone from Eglets viscosa. Planta Med. 63: 146-149.

Rifat-uz-Zaman, M., Akhtar, S. and Khan, M. S. (2002). Evaluation of acid buffering and pepsin binding properties of Ispaghula (Plantago ovata, Forsk) and its extracts. Hamdard, XLV: 32-36.

Sckiguchi, H., Hamada, H., Aijima, H., Taga, F., Uchida, H. and Nishino, K. (1993). Healingpromoting action of the new $\mathrm{H} 2$-receptor antagonist N-ethyl-N[3-[3-(piperidinomethyl) phenoxy] propyl] urea with dual action on chronic gastric and duodenal ulcers induced by acetic acid in rats. Arzneium-Forsch/Dmg Res., 43: 139-1 43.

Zaidi, T. and Mukerji, B. (1958). Experimental peptic ulceration $b$ (Part II). The significance of mucus barrier. Indian J. Med. Res 46: 27-37. 